\title{
WCSJ2017: a bridge to the developing world
}

\section{Conference}

\section{Reviewed by}

Abstract

Keywords

DOI

10TH WORLD CONFERENCE OF SCIENCE JOURNALISTS, SAN FRANCISCO, U.S.A., 26-30 OCTOBER 2017

\section{Paula Leighton}

The 10th World Conference of Science Journalists (San Francisco, U.S.A., 26-30 October 2017) was the most successful to date in terms of participants and probably the one with the largest presence of journalists from the developing world among its attendees and speakers. In agreement with the times, its themes were marked by ethical dilemmas in the communication of science, fake news and climate change, among others.

Professionalism, professional development and training in science communication; Science and media; Science communication in the developing world

https://doi.org/10.22323/2.17010603

Going well beyond a mere reference to the iconic Golden Gate, the $10^{\text {th }}$ World Conference of Science Journalists held in San Francisco, California (WCSJ2017 http:/ /wcsj2017.org/) did keep the promise contained in its title Bridging Science and Societies.

For five days, the 1,300 attendees from 70 countries - the largest turnout for a WCSJ to date - had the opportunity to participate in 61 sessions where they discussed ethical dilemmas, new horizons in science, challenges in global health and the pressures of a changing climate, as well as the challenges science journalism is presented with at a time when science appears to be under attack.

Organized by the National Association of Science Writers (NASW), the Council for the Advancement of Science Writing (CASW), and the World Federation of Science Journalists (WFSJ), the first WCSJ ever held in the United States did fulfill the promise made at the 2015 conference in Seoul, when San Francisco was chosen as its next host city: "serve the needs of a broad spectrum of journalists, especially those from developing countries [...] and strengthen existing and emerging networks with science journalists from Latin America, a region that has been underrepresented at WCSJ." 
Attendance from the developing world was much higher than at previous conferences. And not only in the audience. In most of the panels, journalists from low and middle income nations shared their vision and work experiences in circumstances that are often very complicated in political and cultural terms.

In the session entitled Science Journalism in Latin America: Past, Present and Future, journalists from Argentina, Chile, Colombia, Mexico and Uruguay outlined the ups and downs of the profession in their countries, whereas the plenary session on Science Journalism, Authoritarian Regimes, and Pseudoscience aimed to illustrate the difficulties faced by journalists from Brazil, Costa Rica, Indonesia, Egypt and South Africa in their daily work.

The same subject was covered in the session on Conflicts of Interest for Freelance Science Journalists, in which panelists from Argentina and Egypt participated along with colleagues from Australia and the United States.

In addition, scientific disseminators from South Africa, Mexico and India presented their vision on the role of journalists from the Global South during the session called Decolonizing Science, which is marked by the bias of the English language and its focus on the western northern hemisphere.

The special attention paid by NASW and CASW to Latin America was reflected in the preconference workshop entitled Post Zika in Latin America and the Caribbean and in a special edition of the Science Journalism Workshop addressed to Latin American and Caribbean journalists organized by the Fundación Ealy Ortiz from Mexico. This initiative brought together 70 journalists from 14 countries for a whole day.

Unfortunately, despite being long hoped-for, the establishment of a Latin American network of science journalists remained a mere intention, as no concrete plans were made to identify a path to give life, funds and stability to an organization that would foster the spreading of transnational stories as well as promote professional training and the establishment of further national associations of science journalists, currently in place exclusively in Argentina, Chile and Mexico.

During the second day, the Middle East and Africa led a busy lunch session on the participation of women in STEM. The Princess of Jordan, Sumaya bint El Hassan, President of the Royal Scientific Society, proposed extending STEM mentoring across national borders "to increase the diversity and quality of research."

Furthermore, the Minister for Science and Technology of South Africa, Naledi Pandor, silenced the tinkling of knives and forks with the strength and determination with which she advocated policies that encourage the inclusion of women and black people in such areas. "Women will be the future of science and Africa must be part of that future," she said.

Obviously, the WCSJ2017 programme was not immune to the influence of the current climate that sees science being put into question and science journalism having to face the challenges arising in this Donald Trump era. 
The opening talk was given by John P. Holdren, a Professor of environmental policy at Harvard University and an adviser to former President Barack Obama on science and technology issues. Holdren emphasized that investing in the mitigation of climate change is essential and that confronting those who deny its existence is now urgent. "A president without scientific insights is someone not prepared to get good advice and reject bad," he said.

And the Interactive WCSJ House of Commons Debate went straight to the point, with a discussion on whether science journalists should stay on the sidelines during "the age of Trump and anti-science fake news, with government agencies denying climate change and undercutting childhood vaccination."

The crossing between ethics and scientific progress was another of the topics featured in the programme.

In her opening plenary address Rewriting the Code of Life, Jennifer Doudna, the biochemist and academic at UC Berkeley who co-discovered the CRISPR gene editing technique, maintained that "CRISPR should not be used clinically in human embryos today."

In her opinion, the worst scenario for this promising advancement would be that "something that is perceived or done in a wrong way hinders the advancement of this technique that can generate wonderful possibilities."

A few hours earlier, in a thought-provoking symposium on Human Gene Editing: Is There A Parental Obligation To Create 'Better' Babies?, Ronald Greene, an expert in genetic and biomedical ethics and author of Babies by Design supported gene editing to eliminate serious diseases, but rejected unnecessary physical improvements, warning about the risk that genetic manipulation and money will lead to a form of "genetic nobility."

Without any doubt San Francisco was a great location for the conference. The city opened its doors to attendees with visits to the facilities of the universities of California in San Francisco and Berkeley, stimulating lunches with their researchers, as well as excursions to research centres in the Bay Area.

And with the attendees being science journalists, the opening and closing events could not have had a better location than the terrific Museum of the California Academy of Sciences (www.calacademy.org/) and the Exploratorium (www.exploratorium.edu), where participants spent the night having fun with nearly 600 interactive science activities.

As concerns the choice of the next WCSJ host city, Montreal - though with a weak support - had to compete with an attractive and well-founded joint proposal from the associations of science journalists from Switzerland, France and Italy.

After beating Montreal with their strong joint proposal, the science journalists' associations of Switzerland, France and Italy will therefore host the next WCSJ, which will take place in Lausanne, Switzerland, in July 2019 (www.wcsj2019.eu/), with a special focus on the French-speaking community and the special participation of Eastern European science journalists, as announced by Olivier Dessibourg, President of the Swiss association (SASJ). 
After crossing bridges in San Francisco, the objective set by the Alpine consortium for the next Conference is "to reach new heights." And their proposal bodes really well.

Translated by Massimo Caregnato

Author

Paula Leighton is a journalist from Santiago, Chile. She writes about health, science and environmental issues for the Life, Science and Technology section of El Mercurio newspaper and she also collaborates on a regular basis with SciDev.Net. E-mail: pauleighton@gmail.com.

How to cite

Leighton, P. (2018). 'WCSJ2017: a bridge to the developing world'. JCOM 17 (01), R03_en. https://doi.org/10.22323/2.17010603. 